\title{
Judicial activism and restraint in the creation of the International Judicial Function
}

Citation for published version (APA):

Ayoub, L. (2021). Judicial activism and restraint in the creation of the International Judicial Function: How have activism and restraint shaped the international courts? [Doctoral Thesis, Maastricht University]. Ridderprint. https://doi.org/10.26481/dis.20210118la

Document status and date:

Published: 01/01/2021

DOI:

10.26481/dis.20210118la

Document Version:

Publisher's PDF, also known as Version of record

\section{Please check the document version of this publication:}

- A submitted manuscript is the version of the article upon submission and before peer-review. There can be important differences between the submitted version and the official published version of record.

People interested in the research are advised to contact the author for the final version of the publication, or visit the DOI to the publisher's website.

- The final author version and the galley proof are versions of the publication after peer review.

- The final published version features the final layout of the paper including the volume, issue and page numbers.

Link to publication

\footnotetext{
General rights rights.

- You may freely distribute the URL identifying the publication in the public portal. please follow below link for the End User Agreement:

www.umlib.nl/taverne-license

Take down policy

If you believe that this document breaches copyright please contact us at:

repository@maastrichtuniversity.nl

providing details and we will investigate your claim.
}

Copyright and moral rights for the publications made accessible in the public portal are retained by the authors and/or other copyright owners and it is a condition of accessing publications that users recognise and abide by the legal requirements associated with these

- Users may download and print one copy of any publication from the public portal for the purpose of private study or research.

- You may not further distribute the material or use it for any profit-making activity or commercial gain

If the publication is distributed under the terms of Article $25 \mathrm{fa}$ of the Dutch Copyright Act, indicated by the "Taverne" license above, 


\section{SUMMARY}

Judicial activism and restraint: two elusive and highly controversial terms which have given rise to numerous discussions and debates, both at national and international level alike. While domestic legal scholars have begun attributing these terms particular definitions and criteria for their identification, the international literature on these two concepts has retained a descriptive character, particularly since the international legal system has largely been considered without its judicial component. Furthermore, the effect of activism and restraint upon the judicial function has also been primarily left outside any discussion on their use. This thesis therefore examines how these two concepts have helped shape the international judiciary through their influence on the judicial function, beyond merely identifying the instances where these concepts have been used.

To do this, the analysis begins by drawing upon the theoretical backdrop that enables us to carry out our evaluation, such as defining the international legal system and identifying the main elements of the international judicial function. Within this first section we also identify the manifestations of international law that will allow us to carry out a multi-jurisdictional, and effectively international, analysis without comparing apples with oranges. The second chapter continues in this vein of ascertaining the nature of judiciaries through their methodologies of interpretation, as well as defining what activism and restraint are, and setting out the criteria through which we identify them. Both these chapters create the boundaries which we will be basing our analysis on.

The second section of this thesis (Chapters 3, 4 and 5) form the substantive analysis of our problem question, evaluating the case-law of international courts and tribunals through the lenses created in the first section. It is in these chapters where instances of activism and restraint are examined within the criteria we set in Chapter 2, in order to better understand how the two concepts have been used as tools in furthering the judicial function. The third and final section of the thesis carries out the evaluation of the practice of international courts and tribunals vis-à-vis the theoretical backdrop set out in Chapter 1, by looking at how the judicial function has changed as a result of activism and restraint and in spite of the limitations of the international legal system. It is in this final section that the main question of how judicial activism and judicial restraint have created and shaped the international judicial function is answered. 